DOI 10.18551/rjoas.2019-03.18

\title{
INFLUENCE OF SPECIALIZATION, SIZE AND TENURE OF AUDIT FIRM ON EARNING MANAGEMENT OF MANUFACTURING COMPANIES LISTED ON BEI DURING 2014-2016
}

\author{
Praananta Okky Widya \\ Faculty of Economics and Business, University of Airlangga, Surabaya, Indonesia \\ E-mail: okky wp@yahoo.com
}

\begin{abstract}
This research was conducted to determine the effect of audit quality tested with three variables, namely Audit Firm Specialization, Audit Firm Size, and Audit Firm Tenure on earning management. The population taken in this study was manufacturing companies listed on the Indonesia Stock Exchange for the 2014-2016, and samples taken based on several criteria, namely: (a) listed companies during the observation period, (b) companies not IPO during the observation period, (c) the company is not delisted in the observation period, etc. From these criteria, 202 sample companies will be tested using the SPSS technique. The results obtained from this study were (1) Audit Firm Specialization influence on earning management was rejected (2) Audit Firm size had an influence earning management was rejected, and (3) Audit Firm tenure had an influence on earning management was rejected.
\end{abstract}

\section{KEY WORDS}

Audit firm specialization, audit firm size, audit firm tenure, earning management.

Company management has responsibility on operational and non-operational activity result reporting through financial statement toward shareholders. Company management performance reflected on profit outlined in financial statement, therefore profit information is crucial information as investment decision making basis that interest difference might occur between management and financial statement user due to provided information discrepancy. This profit information frequently becomes management opportunistic falsification action target to maximize their interest, that it could harm investors. Behavior of regulating company profit according to management desire is known as earning management.

Earning management considered as negative issue for several parties as management generally present profit reflected on financial report that is not congruence with actual condition. Earning management incur as agency issue impact namely interest inconsistency between manager and company owner due to information asymmetry, imbalance condition in information attainment between management and shareholders where management have more information than external parties. In other words earning management practice are profit reporting practice that reflect management desire instead of company desire (Levitt $A$. Jr.,1998), that this policy frequently considered as opportunistic action, in which management act on their own interest (Wibisono Haris, 2004) and eventually competent and independent third party roles required to conduct examination on financial report to recover financial report user trust as its target is generating more trusted and accurate financial report according to prevailing accounting regulation (Al-Thuneibat, Al Issa, \& Baker, 2011).

Public accountant are the most precise profession as third party as they take role as auditor to conduct "trust allotment" function through financial report audit. Audit on financial report intended to lower information risk and improve decision making process (Arens, Elder, \& Beasley, 2008). Audit process designed to determine whether figures reported in financial report present correct company operational result and financial position with fair methods (AlThuneibat et al., 2011).

According to DeAngelo (1981) judgment basis for incentive allocation could be made as accountant office, where large public accountant office would certainly sought to present better audit quality compared to small public accountant office. Meanwhile according to 
Arnett and Danos (1979) Audit Firm (Public Accounting Firm) size could not be made as basis of certain work succeed, as long as its professional standard and qualification maintained then it would not be ethical to compare Audit Firm Big Four and non-Audit Firm Big Four.

According to Johnson, Khurana, and Reynolds (2002) research generated showed insufficient understanding on client at initial assignment could lower auditor ability in detecting material error, and lower audit quality. Therefore, long enough service period and experience of accountant could increase auditor ability in detecting misstatement within financial report. However in Indonesia auditor assignment period has been currently regulated in Government Regulation Number 20 Year 2015, in which audit assignment period is maximum 5 consecutive years. Therefore it is expected that through this assignment limitation, audit quality from Audit Firm and trust on financial report presentation conformity maintained and could minimize audit risks.

Audit Firm specialization is expertise in industry formed through repetition of audit setting on same company. The more frequent Audit Firm conducting audit process and similar company type, the more increased knowledge to detect audit risk on such company.

Several researches relevant with this research had been numerously conducted. Amongst them were Christian and Nugrahanti (2014) research generating conclusion that Audit Firm size did not significantly influence on earning management, Farmansyah (2014) research that generating conclusion that audit tenure did not significantly influence on earning management level, Audit Firm size negatively influenced on earning management, Arfan (2013) generating conclusion that Audit Firm size and Audit Firm tenure negatively influenced on accrual management, Inaam, Khmoussi, and Fatma (2012) generating conclusion that Audit Firm size negatively influenced on accrual earning management, Audit Firm size positively influence on real earning management meanwhile audit tenure did not influence on earning management, Gerayli, Yanesari, and Ma'atoofi (20110 generating conclusion that Audit Firm had significant negative influence on earning management.

Meanwhile, contrary research result found by Rusmin (2010) that generating conclusion that auditor quality generating low accrual discretionary and Luhgiatno (2008) that generating conclusion that Big Four Audit Firm could not limit company earning management practice that they audit. Previous research result inconsistency causing research on earning management even interesting and crucial to discuss, that researcher motivated to reexamine Audit Firm specialization, Audit Firm size, Audit Firm tenure influences on earning management on manufacturing companies listed on BEI of 2014-2016 period. This research sample collection justification is on company type and this period were taken as on such period new Government Regulation had been released that it limited longer assignment process and manufacturing companies tend to conduct earning management practice due to high cost and quite large company number that might be tested and could become renewability on this research.

This research result expected to provide benefit for subsequent researcher and enrich other researcher to develop this research, especially for those desiring to examine research with different kind of company. It also be expected to become consideration for company or investors in terms of investment judgment by observing several factors within research, and provide beneficial contribution for government and legislation policy maker as consideration of financial report issuance utilized by most of investors.

\section{LITERATURE REVIEW}

Stewardship theory originated from human behavior model difference applied within organization. This behavior model is self-serving model and pro-organizational behavior model (Walker \& Davis, 1997) in (Luhgiatno, 2008). Based on self-serving behavior model, agency theory developed. Stewardship theory developed on basis of pro-organizational behavior model. This theory assumes that "manager is good and industrious company servant to achieve high profit level and capital return level for shareholders." Therefore manager could be motivated by achievement and need of responsibility and working with 
own initiative. Manager would act according to what company desire to attain (proorganizational behavior).

Stewardship theory is consistent with organizational theory that perceive organization as set of smart man that consistently oriented on organizational objective attainment (Walker \& Davis, 1997) in (Luhgiatno, 2008). Psychological factors behind stewardship theory perceive human as more complex and more humanist creature. Walker and Davis (in Luhgiatno, 2009) characterized human model as self-actualization. This model based on perspective that human has need to grow outside their current and attains higher attainment level.

Agency theory is one of game theory form, a contractual model between two people (parties) or more, that described relationship between agent (business management) with principal (business owner). According to Eisendhardt (1989), agency theory intended to overcome issues on agency theory and regulated contract regulating relationship between principal and agent by considering the following three assumptions:

There are three inevitable human basic natures according to this assumption. They are: (1) self-interest (more self-accentuate or self-prioritize), (2) Bounded rationality (having limited rationality), and (3) Risk aversion (avoid risk).

Organizational assumption referred to herein describes that in organization, human is creature with certain objective and sought to have certain attainment amongst other organizational members.

This assumption describes that for human information serves as purchasable commodity. According to Scott (2009), there are two kinds of informational asymmetry namely adverse selection and moral hazard. Adverse selection occurs as company management party and other internal parties have better knowledge on current condition and future company prospect compared to investors outside company.

Company perceived as contract between employee, manager, supplier and capital supplier that constitute center of company operation. Company would minimize various contract costs in connection with contract such as negotiation, contract performance monitoring, renegotiating costs and costs expected from bankruptcy and other failures. Positive accounting theory describes why company optimizes accounting policy as part of deep issues from minimizing contract cost and attaining corporate governance efficiency.

Three PAT hypotheses made as earning management action basic understanding by Watts and Zimmerman (1986) are as follow:

In company with bonus allocation plan, company manager would prefer accounting method that could shift profit from future into current condition that it could increase current profit. This is due to manager prefer higher remuneration allocation for current condition. There are two terms in bonus contract, namely bogey (lowest profit level to attain bonus) and cap (highest profit level). If profit fall under bogey, no bonus that manager shall attain, meanwhile if profit higher than cap, no additional bonus for the manager. If net profit fall under bogey, manager tend to cut down profit by expecting for higher bonus for subsequent period, likewise if profit higher than cap. Therefore only when net profit range between bogey and cap, manager would seek to increase company net profit.

In company with high debt to equity ratio, company manager tend to utilize accounting method that could increase earning or profit. Company with high debt to equity ratio would experience difficulty in attaining additional funds from creditor and even company threatened in violating debt agreement.

In large company with high political costs, manager would prefer accounting method that suspends profit reported from current period into future period that it could minimize reported profit. Political costs incur due to high company profitability could attract media and consumer attention.

Audit generally categorized into the three following types (Arens et al., 2008). Financial report audit intended to determine whether entire financial report as measured information to verify has been presented in compliance with certain criteria. Generally, those criteria are accounting principles that commonly prevail. Financial report audit composed according to 
cash basis or other accounting basis are also frequent according to the respective organizational needs.

Operational audit is review of part as well as operational procedure and method of organization to assess its efficiency and effectiveness. Generally, as this operational audit completed, auditor would provide several suggestions for management to improve company operational.

Compliance audit intended to consider whether auditee (client) has followed procedure or regulation already stipulated by party with higher authorization.

According to Healy and Wahlen (1999), "Earning Management occurs when managers use judgment in financial reporting and in structuring transaction to alter financial reports to either mislead some stakeholders about the underlying economic performance of the company or to influence contractual outcomes that depend on reported accounting numbers". Setiawati and Na'im (2000) described that earning management is management intervention effort within external financial reporting process for their own benefit.

In contrary with Harahap (2011) in Pradani (2013), earning management is effort of managing Earning Management profit that in accounting dictionary referred to as window dressing or accounting lipstick to create more beautiful financial report. Scott (2012) stated that earning management is one of manager option concerning accounting policy or actual action that could influence earning that company profit could be arranged.

Based on several above definitions it could be concluded that earning management is intentional intervention by management within company financial report process into company external party utilizing their judgment to influence its users decision for the sake of personal benefit.

\section{HYPOTHESIS DEVELOPMENT}

Auditor with numerous clients with similar company type would have better understanding and knowledge concerning such company type. Knowledge on company internal control, business risk, and audit risk on such company type becomes more sufficient. Several research which amongst them according to Carcelo and Nagy (2002) generated evidence where client of specialist auditor more rarely interact with SEC sanction in United States of America. Jenkins et al. (2006) result suggested that high audit quality require auditor with industry specialization that trust level on profit quality shall be better, where it aligns with auditor understanding on audited company type.

Several researches showed that client with financial report audited by auditor with industry specialization would have lower discretionary accruals compared to client without specialization (Balsam et al., 2003. However as Audit Firm specialization still unable to directly observed, this research used different measurement from previous existing research.

Second research from Jenkins et al. (2006) recommended that for higher audit quality, auditor quality utilization with industry specialization is expected to improve audit quality. And auditor with industry specialization shall be better in detecting misstatement on similar industry specialization compared to different industry type (Owhoso et al., 2002). Based on such several researches the following is formulation for first hypothesis:

$\mathrm{H} 1$ : Audit Firm specialization negatively influence on earning management.

Audit company size according to Deis Jr and Giroux (1992) measured from total client and percentage from audit fee in effort maintaining its client from moving into other audit company. Research carried out by DeAngelo (1981) argument that audit quality directly related to audit company size with proxy for audit company size is total client. Large audit companies are those with more total client. This research showed that large audit company would sought to provide better audit quality compared to small audit company. As large company audit would lose its reputation for not providing high quality auditing, and this would certainly bigger lost than loosing client.

According to DeAngelo (1981), Audit Firm size could provide added value to provide better audit quality compared to small Audit Firm, meanwhile according to Arnett and Danos (1979), Audit Firm size could not be made as basis for certain work succeed. As long as 
Audit Firm could maintain their professional standard and qualification then it would not be ethical to distinguish Big Eight Audit Firm with other than Big Eight Audit Firm.

In terms of Audit Firm size according to Francis and Yu (2009), larger AUDIT FIRM size would generate higher audit quality. In addition, Choi, Kim, Kim, and Zang (2010) also discovered consistent result. This research used discretionary accrual for Audit Firm size using total client. According to above theory understanding, second hypothesis of this research is:

$\mathrm{H}_{2}$ : Audit Firm size negatively influence on earning management.

Audit tenure is assignment duration established between auditors with audit service client (Al-Thuneibat et al., 2011). Myers, Myers, and Omer (2003) defined audit tenure as total auditor years in auditing their client. Therefore audit tenure is duration of an auditor conducting audit on company measured in year.

According to Decree of Capital market Financial Institution Supervision Board Chairman Number: KEP-310/BL/2008 on audit period assignment limitation section described that general audit service provision for client financial report could only be performed by Audit Firm (Public Accounting Firm) for 6 (six) consecutive fiscal years at the longest and 3 (three) consecutive fiscal years for a Public Accountant.

However regulation used in this research was not in accordance with Government Regulation of the Republic of Indonesia Number 20 Year 2015 concerning Public Accountant Practice on section $V$ concerning audit limitation service, on article 11 paragraph 1 stated that audit service provision for historical financial information as referred to in article 10 paragraph (1) point a on certain entity by a public accountant limited for 5 (five) consecutive fiscal years at the longest.

Tenure commonly associated with its influence on auditor independence. Long relationship between Audit Firm and client potentially inflicting closeness between those parties, and it could impede auditor independence and reducing audit quality (Al-Thuneibat et al., 2011).

Long relationship between Audit Firm and client could also inflict Audit Firm closeness with company management that causing independence attitude becomes hard to apply by Audit Firm (Dao, Mishra, \& Raghunandan, 2008).

$\mathrm{H}_{3}$ : Audit Firm Tenure negatively influence on earning management.

\section{METHODS OF RESEARCH}

Populations are complete element group, commonly in form of person, object, transaction, or incidence where we interested in learning them or become research object (Kuncoro, 2003).

Populations in this research were entire company listed on Indonesian Stock Exchange (BEI) in 2014-2016. The following are population criteria:

1. Company issuing financial report and/or annual report in 2014-206 period;

2. Company fully operated during 2014-2016 and not included in Initial Public Offering (IPO) within observation period;

3. Company not making delisting from BEI, not terminating operational activity, not conducting business merger and not changing sector status within observation period;

4. Company presenting financial report stated in Rupiah;

5. Company outside financial industry sector;

6. Public Accountant Office name that audit company financial report, clearly outlined on financial report published by BEI.

Manufacturing company populations categorized into three of the following industry sectors, fundamental and chemical industry sector.

According to Kuncoro (2003), variable is something that could distinguish or change value. Value could be different for exact object, or it could be different in exact time for different object. This research used three kinds of variable, independent variable, intervening variable and dependent variable. 
Dependent variable is variable influenced by independent variable existence (Sugiyono, 2011). This research used earning management as its dependent variable. Earning management defined as policy that could intervene company external party using financial report to influence decision to attain personal benefit. On this research earning management used model (DeAngelo, 1981) where total accruals comprised of discretionary accrual and non-discretionary accrual, where total accruals deemed hard to observe. This approach assumes non-discretionary accrual component tend to be stable across time that making discretionary accruals component worth considered. Therefore, if discretionary accrual has average equal to zero during estimation period than this model is worth used to measure discretionary accrual without mistake. Discretionary accruals level calculation initiated with total accruals calculation. Total accruals formula (Teoh et al., 1998):

$$
\mathrm{TACt}=(\mathrm{Nlt}-\mathrm{CFFOt})
$$

Where: TACt $=$ Total accruals on year $\mathrm{t}$ period; NIt $=$ Net income on year $\mathrm{t}$ period; CFFOt $=$ Cash flow from operation on year $t$ period.

DeAngelo (1986) assumed that non-discretionary total accruals following random walk pattern. Therefore non-discretionary total accruals (fair or normal accrual level) on t period assumed as similar with non-discretionary total accruals on $\mathrm{t}-1$ period:

$$
\text { NDAt }=\text { TACt }-1
$$

Where: NDAt $=$ Non-discretionary Accruals on $\mathrm{t}$ period; TACt- $1=$ Total accruals on $\mathrm{t}-1$ period.

Upon calculating NDAt, DAt size could be calculated with the following formula:

$$
\mathrm{DAt}=(\mathrm{TACt}-\mathrm{NDAt}) / \mathrm{TAt}
$$

Where: DAt $=$ Non-discretionary Accruals on t period; TACt $=$ Total accruals on $\mathrm{t}-1$ period; NDAt $=$ Non-discretionary Accruals on $t$ period; TAt $=$ Total assets on $\mathrm{t}-1$ period .

Independent variable is variable influencing related variable (Sugiyono, 2011). Independent variables used in this research were Audit Firm specialization, Audit Firm size and Audit Firm tenure.

Audit Firm Specialization $\left(X_{1}\right)$. Audit Firm with industry specialization are those performing audit process on specific sector such as manufacture, banking, etc., and having more reliable experience on such sector (Lee, 2007). Industry specialization measurement measured using dummy variable, using scale 1 if on one assignment year Audit Firm conducting audit on similar sector for minimum $10 \%$ on single industry type and scale 0 if less than $10 \%$.

Audit Firm Size $\left(X_{2}\right)$. Audit Firm size determined using rank for total client audited divided by total company listing on one assignment year. The higher total company percentage, the higher company rank level and determine such Audit Firm audit quality.

Audit Firm Tenure $\left(X_{3}\right)$. Audit Firm tenure is audit assignment period between Audit Firm and audit service related client that previously agreed. Audit Firm tenure variable was dummy variable, using scale 0 for Audit Firm with assignment period 0-2 years and 1 for Audit Firm with 3-5 years assignment period.

Auto correlation is statistical analysis conducted to discover variable correlation exist in prediction model with time change. Therefore, if auto-correlation assumption occur on prediction model, then disturbance value no longer freely associate, but associate in autocorrelate manner.

\section{RESULTS AND DISCUSSION}

Research data originated from annual report of manufacturing companies listed on Indonesian Stock Exchange (BEI) on 2014-2016 period. Such data obtained through 
downloading from www.idx.com or each company sites. From data obtained on Indonesian Stock Exchange, samples were obtained for observation period of 2014-2016 as of 202 companies.

Researcher conducted descriptive statistics analysis to discover data distribution from research sample and descriptive statistic testing result generating minimum value, maximum value, median and standard deviation from each research variable.

Table 1 - Descriptive Statistics

\begin{tabular}{|l|c|c|c|c|c|}
\hline \multicolumn{1}{|c|}{$\mathrm{n} / \mathrm{n}$} & $\mathrm{N}$ & Minimum & Maximum & Mean & Std. Deviation \\
\hline Audit Firm Specialization & 202 &, 00 & 1,00 &, 9158 &, 27831 \\
\hline Audit Firm Size & 202 &, 00 & 1,00 &, 8218 &, 38365 \\
\hline Audit Firm Tenure & 202 &, 00 & 1,00 &, 9802 &, 13967 \\
\hline Earning Management & 202 &, 00 &, 86 &, 0771 &, 11934 \\
\hline Valid N & 202 & - & - & - & - \\
\hline
\end{tabular}

Descriptive statistic testing result showed that Audit Firm specialization variable on 2014-2016 measured using dummy variable, using scale 1 if on one year of assignment Audit Firm conducting audit process on company of similar sector for minimum $5 \%$ on single similar industry type and scale 0 if less than $5 \%$. The 202 samples had minimum value of 0 and maximum value of 1 , with mean (average) of 0.9158 and standard deviation of 0.278 . Such values described even lower distribution and data variation, as it had standard deviation lower than mean value $(0.27831<0.9158)$.

Descriptive statistic testing result for Audit Firm size variable on 2014-2016 period measured using rank for number of client audited on observation period on 15 Audit Firm with the most auditee had score 1 and 0 for below 15. The 202 samples had minimum value of 0 and maximum value of 1 , with mean (average) of 0.8218 and standard deviation of 0.38365 . Such values described even lower distribution and data variation, as it had standard deviation lower than mean value $(0.38365<0.8218)$.

Descriptive statistic testing result for Audit Firm tenure variable on 2014-2016 period from 202 samples had minimum value of 0 and maximum value of 1, with mean (average) of 0.9802 and standard deviation of 0.13967 . Such values described even lower distribution and data variation, as it had standard deviation lower than mean value $(0.14<0.98)$.

Descriptive statistic testing result for earning management variable on 2014-2016 period from 202 samples had minimum value of 0.00 and maximum value of 0.86 , with mean of 0.0771 and standard deviation of 0.11934 Such values described even lower distribution and data variation, as it had standard deviation lower than mean value $(0.11934<0.0771)$.

Auto-correlation test is statistical analysis used to discover variable correlation in certain prediction model with time change. This research showed that no correlation occur between residual, marked from DW (Durbin Watson) value of 2.004 which means between -2 and +2 , that it could be concluded that multiple linear regression model generated no autocorrelation occur and feasible to use.

Multicollinearity test is certain situation represented with strong correlation or relationship between two or more independent variable in certain multiple regression model. Test used to discover multicollinearity existence is VIF. If VIF $>10$ then multicollinearity occur between independent variables and VIF $<10$ represents no multicollinearity between independent variables. The following are VIF result on each independent variable:

Table 2 - VIF (Variance Inflation Factor) Result

\begin{tabular}{|c|c|}
\hline Dependent Variables & VIF \\
\hline Audit Firm Specialization $\left(X_{1}\right)$ & 0.024 \\
Audit Firm Size $\left(X_{2}\right)$ & 0.034 \\
Audit Firm Tenure $\left(X_{3}\right)$ & 0.014 \\
\hline
\end{tabular}

According to Table 2 it could be concluded that no multicollinearity on regression model, as VIF value generated by Audit Firm Specialization $\left(\mathrm{X}_{1}\right)$, Audit Firm Size $\left(\mathrm{X}_{2}\right)$ and 
Audit Firm Tenure $\left(\mathrm{X}_{3}\right)$ were lower than 10. Therefore regression model from the least square method (OLS) could be used.

Hypothesis test in this research used multiple regression analysis. $H_{1}, H_{2}$, and $H_{3}$ hypothesis shall be tested using the following empirical model:

$$
\text { ABSDA }=\alpha+\beta 1 \text { AF-SPEC }+\beta 2 A F-S I Z E+\beta 3 A F-T E N U R E+\varepsilon
$$

Where: $\alpha=$ constant; $\beta=$ variable coefficient; ABSDA = absolute value from discretionary accruals (earning management). Absolute value used as discretionary accruals size are concern of this research, instead of its direction (positive or negative) (Balsam et al. 2003); AF-SPEC = Audit Firm specialization, score 1 if company audited by auditor industrial specialization and 0 if others; AF-SIZE = Audit Firm size, score 1 if company audited by Audit Firm with high rank and 0 if others; AF-Tenure $=$ Audit Firm tenure if company audit for more than or equal to three years (score 1), and score 0 if others; $\varepsilon=$ residual of error.

Table 3 - Hypothesis Test Result

\begin{tabular}{|c|c|c|c|c|}
\hline Dependent Variables & Regression Coefficient & Std. Error & $\mathrm{t}$ & Sig \\
\hline Audit Firm Specialization $\left(\mathrm{X}_{1}\right)$ & $-0,038$ & 0,035 & $-1,065$ & 0,288 \\
\hline Audit Firm Size $\left(\mathrm{X}_{2}\right)$ & $-0,004$ & 0,026 & $-0,152$ & 0,879 \\
\hline Audit Firm Tenure $\left(\mathrm{X}_{3}\right)$ & 0,038 & 0,061 & 0,620 & 0,536 \\
\hline $\begin{array}{l}\text { Dependent variables: Earning Manage } \\
\text { Constant: } 0,078 \\
\text { Correlation Coefficient }(R)=0,101 \\
\text { Determination Coefficient }\left(R^{2}\right)=0,010\end{array}$ & & & & \\
\hline
\end{tabular}

Table 4 - Analysis of Variance (ANOVA)

\begin{tabular}{|c|c|c|c|c|c|}
\hline Variance Source & Total Square & df & Middle Square & F & Sig \\
\hline Regression & 0.029 & 3 & 0.010 & \multirow{2}{*}{0.676} & 0.568 \\
Residual & 2.834 & 198 & 0.014 & & \\
Total & 2.863 & 201 & & & \\
\hline
\end{tabular}

According to Table 4, the following multiple regression analysis obtained:

$$
Y=0,078-0,038 X 1-0,004 X 2+0,038 \times 3
$$

Based on above equation, it could be described as follow: $a=$ Constant $=0,078$.

Constant value of 0.078 means that Earning Management $(Y)$ is constant with assumption that Audit Firm Specialization variable $\left(X_{1}\right)$, Audit Firm Size $\left(X_{2}\right)$ and Audit Firm Tenure $\left(\mathrm{X}_{3}\right)$ in constant condition.

b1 $=$ Regression Coefficient for $X_{1}=-0.038$.

This showed Audit Firm Specialization Variable $\left(X_{1}\right)$ influence size on earning management, which means if Audit Firm specialization variable increase 1 point then earning management value would reduce as of 0.038 point with assumption that other independent variables are constant.

b2 = Regression Coefficient for $\mathrm{X}_{2}=-0.004$

This showed Audit Firm Size Variable $\left(X_{2}\right)$ influence size on earning management, which means if Audit Firm size variable increase 1 point then earning management value would reduce as of 0.004 point with assumption that other independent variables are constant.

b3 = Regression Coefficient for $X_{3}=0.038$.

This showed Audit Firm Tenure Variable $\left(X_{3}\right)$ influence size on earning management, which means if Audit Firm tenure variable increase 1 point then earning management value would reduce as of 0.038 point with assumption that other independent variables are constant or equal to 0 .

Adjusted $R^{2}$ (determination coefficient) value was 0.010 that represented independent variable ability in influencing dependent variable was 0.010 . It means that accuracy level 
from being able to account for relationship between Audit Firm specialization, Audit Firm Size and Audit Firm Tenure with earning management variable was $1 \%$. Meanwhile the remaining $99 \%$ accounted by other variable. Multiple correlation coefficient was 0.101 which means weak correlation between independent variable with dependent variable was $10.1 \%$.

Audit Firm Specialization Influence on Earning Management. According to hypothesis test result using SPSS software showed that Audit Firm Specialization did not influence on earning management, evidenced from $\beta$ value of -0.038 and $p$-value of 0.288 (higher than significance level of $10 \%$ or 0.10 ), therefore $\mathrm{H} 1$ which stated that Audit Firm specialization influence on earning management is rejected.

This first hypothesis testing result is in line with research conducted by Dian and Yuyetta (2013) showing that auditor industry specialization did not influence on earning management. This research also contrary with Mayhew et al. (2001) research showing that auditor industry specialization assignment could discover earning management, prediction mistake and ability to predict cash flow and future profit admission.

Therefore Audit Firm with industry specialization that should have sufficient understanding concerning industry characteristic, audit standard conformity, and understand more concerning audited industry risk and issue, not certainly better have ability in detecting mistake compared to non-industry specialization, in addition object from manipulation are not financial report but process in cost disclosure that could influence profit.

Audit Firm Size Influence on Earning Management. According to hypothesis test result using SPSS software showed that Audit Firm Size did not influence on earning management, evidenced from $\beta$ value of -0.038 and $p$-value of 0.879 (higher than significance level of $10 \%$ or 0.10 ), therefore $\mathrm{H}_{2}$ which stated that Audit Firm size influence on earning management is rejected.

This second hypothesis testing is in accordance with Febriyanti and Mertha (2014) research stating that Audit Firm size did not influence on earning management. Research carried out by Gerayli et al., (2001), Rusmin (2010) and Inaam et al., 2012) also stated the similar result where Audit Firm size significantly had negative influence on earning management.

In testing of Audit Firm size, researcher made separation with large and small Audit Firm through ranking based on total auditee. According to data from Financial Profession Guidance Center, researcher obtained Audit Firm data with quite striking total auditee on top 15 Audit Firm with total auditee above 2000 and less than 300 total auditee for Audit Firm under top 15. Separation and variable testing then subsequently performed for Audit Firm size with ability to detect higher risk and sufficient knowledge for their numerous auditee totals. Therefore financial report generated could be trusted and according to existing company condition.

Audit Firm Tenure Influence on Earning Management. According to hypothesis test result using SPSS software, Audit Firm tenure did not influence on earning management, observed from $\beta$ value of 0.038 and $p$-value of 0.536 (higher than significance level of $10 \%$ or 0.10) therefore $\mathrm{H}_{3}$ which said that Audit Firm Tenure negatively influence on earning management is rejected.

This research result is in line with Dian and Yuyetta (2013) research, stating that long enough assignment period prone to influence auditor independence but short assignment period could also influence understanding on company condition. This result is in contrary with Deis Jr and Giroux (1992) research, stating that the loner audit period (audit tenure) should make auditor more challenged and innovative on audit procedure. Lavin (1976) in his research also stated that the longer audit period make decreased independence as auditor would have financial independence on client.

Audit Firm with long assignment period should be able to understand company condition and have better understanding company existing risk. However in order to avoid overlong assignment period between Audit Firm and auditee, regulation was enacted in Government Regulation Number 20 Year 2015, intended to avoid strictly close relationship that could reduce financial report quality. 


\section{CONCLUSION AND RECOMMENDATIONS}

Based on research result analysis and discussion previously outlined, there are several conclusion as follows. This research analyzed Audit Firm specialization, Audit Firm size and Audit Firm tenure influences on earning management with samples of 202 companies listed on Indonesian Stock Exchange (BEI) of 2014-2016 period, using 202 companies as samples in this research. This research used multiple linear regression analysis to process data, supported with SPSS software. First hypothesis test result of this research showed that Audit Firm specialization did not influence on earning management. Second hypothesis test obtained in this research showed that Audit Firm size did not influence on earning management. Third hypothesis testing showed that Audit Firm tenure did not influence on earning management.

Researcher recognized several limitations of this research, amongst them researcher found difficulty in obtaining data fee audit that measurement on Audit Firm size variable used rank on auditee total. Such ranking collected based on data from Financial Profession Guidance Center (FPGC) in performing data separation of 15 large Audit Firm with auditee above 1000 (go-public and non go-public) and outside top 15 with auditee total below 300 (go-public and non go-public). This data made as basis for variable testing for Audit Firm size, Audit Firm names from data audit fee from FPGC are disguised, therefore making it difficult to separate.

Further researcher use other measurement tool on Audit Firm size variable, for instance using Audit Firm total assets based on Audit Firm fee from company or total assets of Auditee Company. Secondly, samples should be enlarged for instance through sample that compare cross-country between Audit Firm performing audit process in Indonesia and abroad.

\section{REFERENCES}

1. Al-Thuneibat, A. A., Al Issa, R. T. I., \& Baker, R. A. A. (2011). Do Audit Tenure and Firm Size Contribute to Audit Quality? Empirical Evidence From Jordan. Managerial Auditing Journal, 26(4), 317-334.

2. Arens, A. A., Elder, R. J., \& Beasley, M. S. (2008). Auditing and Assurance Service, An Intergrated Approach (19 Edition ed.). Jakarta: Erlangga

3. Arfan, A. P. (2013). Pengaruh Konvergensi Standar Akuntansi Keuangan (SAK) Berbasis International Reporting Standard (IFRS) Terhadap Kualitas Audit. Universitas Gajah Mada.

4. Arnett, H. (1979). CPA Firm Viability (University of Michigan, Ann Arbor, MI).

5. Balsam, S., Krishnan, J., \& Yang, J. S. (2003). Auditor industry specialization and earnings quality. Auditing: A journal of practice \& Theory, 22(2), 71-97.

6. Carcello, J. V., \& Nagy, A. L. (2004). Client size, auditor specialization and fraudulent financial reporting. Managerial Auditing Journal, 19(5), 651-668.

7. Choi, J.-H., Kim, C., Kim, J.-B., \& Zang, Y. (2010). Audit office size, audit quality, and audit pricing. Auditing: A Journal of Practice \& Theory, 29(1), 73-97.

8. Christiani, I., \& Nugrahanti, Y. W. (2014). Pengaruh Kualitas Audit Terhadap Manajemen Laba. Jurnal Akuntansi and Keuangan, 16(1), 52-62.

9. Dao, M., Mishra, S., \& Raghunandan, K. (2008). Auditor tenure and shareholder ratification of the auditor. Accounting horizons, 22(3), 297-314.

10. DeAngelo, L. E. (1981). Auditor size and audit quality. Journal of accounting and economics, 3(3), 183-199.

11. DeAngelo, L. E. (1986). Accounting numbers as market valuation substitutes: A study of management buyouts of public stockholders. Accounting review, 400-420.

12. Dechow, P. M., Sloan, R. G., \& Sweeney, A. P. (1995). Detecting earnings management. Accounting review, 193-225.

13. Deis Jr, D. R., \& Giroux, G. A. (1992). Determinants of Audit Quality in The Public Sector. Accounting review, 462-479. 
14. Dian, F. D. F., \& Yuyetta, E. N. A. (2013). Pengaruh Arus Kas Bebas, Ukuran KAP, Spesialisasi Industri KAP, Audit Tenur and Independensi Auditor terhadap Manajemen Laba. Diponegoro Journal of Accounting, 166-174.

15. Eisendhardt, K. M. (1989). Agency Theory: An Assesment and Review. Academy of Management Review. 14, 57-74.

16. Farmansyah, D. A. (2014). Pengaruh Audit Tenure, Ukuran Kantor Akuntan Publik and Auditor Spesialisasi Industri Terhadap Manajemen Laba. Universitas Airlangga Surabaya.

17. Febriyanti, N. M. D., \& Mertha, I. M. (2014). Pengaruh Masa Perikatan Audit, Rotasi KAP, Ukuran Perusahaan Klien, and Ukuran KAP Pada Kualitas Audit. E-Jurnal Akuntansi.

18. Francis, J. R. (2008). The joint effect of investor protection and big 4 audits on earnings quality around the world ${ }^{*}$. Contemporary accounting research, 25(1), 157-191.

19. Francis, J. R., \& Yu, M. D. (2009). Big 4 office size and audit quality. The Accounting Review, 84(5), 1521-1552.

20. Gavious, I. (2007). Alternative perspectives to deal with auditors' agency problem. Critical perspectives on Accounting, 18(4), 451-467.

21. Gerayli, M. S., Yanesari, A. M., \& Ma'atoofi, A. R. (2011). Impact of audit quality on earnings management: evidence from Iran. International Research Journal of Finance and Economics, 66, 77-84.

22. González-Díaz, B., García-Fernández, R., \& López-Díaz, A. (2015). Auditor Tenure and Audit Quality in Spanish State-Owned Foundations. Revista de Contabilidad, 18(2), 115126.

23. Harahap, L., \& Wardhani, R. (2011). Analisis komprehensif pengaruh family ownership, masalah keagenan, kebijakan dividen, kebijakan hutang, corporate governance and opportunity growth terhadap nilai perusahaan. Tesis, Program Pascasarjana Fakultas Ekonomi Universitas Indonesia, Depok.

24. Healy, P. M. (1985). The effect of bonus schemes on accounting decisions. Journal of accounting and economics, 7(1), 85-107.

25. Healy, P. M., \& Wahlen, J. M. (1999). A Review of the Earnings Management Literature and Its Implications for Standard Setting. Accounting horizons, 13(4), 365-383.

26. Hendriksen, E. S. (2001). Teori Akuntansi (Alih Bahasa: Nugroho Widjayanto). Jakarta: Erlangga.

27. Inaam, Z., Khmoussi, H., \& Fatma, Z. (2012). Audit quality and earnings management in the Tunisian context. International Journal of Accounting and Financial Reporting, 2(2), 17-33.

28. Jenkins, D. S., Kane, G. D., \& Velury, U. (2006). Earnings quality decline and the effect of industry specialist auditors: An analysis of the late 1990s. Journal of Accounting and Public Policy, 25(1), 71-90.

29. Jensen, M. C., \& Meckling, W. H. (1976). Theory of the firm: Managerial behavior, agency costs and ownership structure. Journal of financial economics, 3(4), 305-360.

30. Johnson, V. E., Khurana, I. K., \& Reynolds, J. K. (2002). Audit-Firm Tenure and the Quality of Financial Reports*. Contemporary accounting research, 19(4), 637-660.

31. Jones, J. J. (1991). Earnings Management During Import Relief Investigations. Journal of Accounting Research, 193-228.

32. Krishnan, J., \& Schauer, P. (2000). The Differfentiation of Quality among Auditors: Evidence from the Not-for-Profit Sector. Auditing: A Journal of Practice and Theory, 19, 2-9.

33. Kuncoro, M. (2003). Metode Riset untuk Bisnis and Ekonomi Jakarta: Erlangga

34. Lavin, D. (1976). Perceptions of the Independence of the Auditor. The Accounting Review, 51(1), 41-50.

35. Levitt, A. (1998). The Number Game, A Speech delivered at The NYU Center for Law of Business, New York: working paper.

36. Li, C., Song, F. M., \& Wong, S. M. (2008). A Continuous Relation Between Audit Firm Size and Audit Opinions: Evidence from China. International Journal of Auditing, 12(2), 111-127. 
37. Luhgiatno, L. (2008). Analisis Pengaruh Kualitas Audit Terhadap Manajemen Laba Studi Pada Perusahaan Yang Melakukan IPO Di Indonesia. Diponegoro University.

38. Mayhew, B. W., Wilkins, M., Giroux, G., Gramling, A., Hogan, C., Holder-Webb, L., . . . Warren, D. (2001). The Impact of Audit Firm Industry Specialization on Fees Charged to Firms Going Public: University of Wisconsin-Madison.

39. Myers, J. N., Myers, L. A., \& Omer, T. C. (2003). Exploring the Term of the Auditor-Client Relationship and the Quality of Earnings: A Case for Mandatory Auditor Rotation? The Accounting Review, 78(3), 779-799.

40. Owhoso, V. E., Messier, J., William F, \& Lynch, J., John G. (2002). Error detection by industry-specialized teams during sequential audit review. Journal of Accounting Research, 40(3), 883-900.

41. Pradani, A. E. (2013). Pengaruh Leverange Keuangan Perusahaan, Ukuran Perusahaan and Kualitas Audit Terhadap Manajemen Laba. Universitas Airlangga Surabaya.

42. Rusmin, R. (2010). Auditor quality and earnings management: Singaporean evidence. Managerial Auditing Journal, 25(7), 618-638.

43. Scott, W. R. (2009). Financial Accounting Theory: Prentice Hall Canada Inc.

44. Scott, W. R. (2012). Financial Accounting Theory (Vol. Sixth Edition): Prentice Hall Canada Inc.

45. Setiawati, L., \& Na'im, A. (2000). Manajemen Laba. Journal of Indonesian Economy and Business, 15(4).

46. Simunic, D. A., \& Stein, M. T. (1996). Impact of litigation risk on audit pricing: A review of the economics and the evidence. Auditing, 15, 119.

47. Sugiyono. (2011). Metode Penelitian Pendidikan. Bandung: Alfabeta.

48. Walker, D. L., \& Davis, M. (1997). Double dissociation between the involvement of the bed nucleus of the stria terminalis and the central nucleus of the amygdala in startle increases produced by conditioned versus unconditioned fear. Journal of Neuroscience, 17(23), 9375-9383.

49. Watts, R. L., \& Zimmerman, J. L. (1986). Positive Accounting Theory.

50. Whittington, O. R. a. P., Kurt. (2002). Principles of Auditing and Other Assurance Service (13 ed.): Boston: McGraw-Hill//rwin.

51. Wibisono, H. (2004). Pengaruh Manajemen Laba terhadap Kinerja Perusahaan di Seputar Seasoned Equity Offerings (Studi Empiris di Bursa Efek Jakarta). Program Pascasarjana Universitas Diponegoro.

52. Wibowo, A., \& Rossieta, H. (2009). Faktor-Faktor Determinasi Kualitas Audit Suatu Studi dengan Pendekatan Earning Surpise Benchmark. Pasca Sarjana IImu Akuntansi Universeitas Indonesia. 